\title{
Climate change and livestock production: A review with emphasis on Africa
}

\author{
J.M. Rust ${ }^{\#}$ \& T. Rust \\ Döhne ADI, Private Bag X15, Stutterheim, 4930, South Africa
}

Copyright resides with the authors in terms of the Creative Commons Attribution 2.5 South African Licence.
See: http://creativecommons.org/licenses/by/2.5/za
Condition of use: The user may copy, distribute, transmit and adapt the work, but must recognise the authors and the South African Journal of Animal
Science.

\begin{abstract}
Climate change and its effects on existence on earth are becoming more and more relevant as physical evidence of change in our climate is beginning to mount. Livestock production and our dependence on it for survival is a reality. It is also a reality that this global source of food and income will be prone to the effects of climate change. Historic climate changes have already played a role in the demise or development of agricultural production systems. This review article will give insight into the most important livestock production species and the possible effects of climate change on their production parameters. The species to be discussed are dairy cattle, beef cattle, small ruminants and monogastric production animals. The results and predictions of global studies and simulations are summarized with special emphasis, where possible, on the southern African scenario. This review deals with these changes and possible adaptations and mitigations. All predictions indicate that livestock production at local, national and regional level may undergo changes in the foreseeable future.
\end{abstract}

Keywords: Climate impact, dairy cattle, beef cattle, small ruminants, monogastric animals

\# Corresponding author: jean.rust@gmail.com

\section{Introduction}

Uncertainty is the most problematic aspect of climate change and is a hugely limiting factor in the prediction and assessment of its effects. At best, a range of high and low extremes with defined probability distribution can be predicted (Jones, 2000). Quantitative simulation studies that estimate the effect of possible future climate change are few. However, the effect of weather and extreme events on several aspects of animal production has been well documented.

Agriculture remains the backbone of most African economies (Hussein et al., 2008). The agricultural sector is the largest domestic producer across the continent and employs between $70 \%$ and $90 \%$ of the total labour force (FAO, 2007). In addition, agriculture supplies up to $50 \%$ of household food requirements and up to $50 \%$ of household incomes. Most of the income is generated by beef cattle, dairy cattle, goats, sheep and chickens. Together these five species generate $92 \%$ of the total revenue from livestock in Africa. In many rural communities, livestock is the only asset of the poor, but it is highly vulnerable to climate variability and extremes (Easterling et al., 2007; FAO, 2007; Thornton et al., 2007; IFAD, 2010). The impact of climate change is expected to heighten the vulnerability of livestock systems and reinforce existing factors that are affecting livestock production systems (Gill \& Smith, 2008).

Agriculture is contributing to climate change as well as being affected by it (Aydinalp \& Cresser, 2008). These facts and figures are quoted in various studies and reports (IPCC, 1996) and are based mostly on commercial agriculture (Koneswaran \& Nierenberg, 2008):

- $\quad$ The three main gas emissions are carbon dioxide $\left(\mathrm{CO}_{2}\right)$, methane $\left(\mathrm{CH}_{4}\right)$ and nitrous oxide $\left(\mathrm{N}_{2} \mathrm{O}\right)$, with methane gas being the most significant of the agriculturally produced gasses (IPCC, 1996).

- $\quad$ The global warming potential of methane and nitrous oxide is approximately 20 and 300 times that of carbon dioxide, respectively (IPCC, 1996).

- Agriculture's contribution as a whole to global warming is estimated at between $18 \%$ and $20 \%$, which according to some sources is higher than that of transportation (This is a misrepresentation since the 
agricultural contribution was calculated on the whole lifecycle of agricultural production and that of transportation was based only on gas emissions during the transportation process and not the rest of the manufacturing processes (Pitesky et al., 2009).

- $\quad$ The livestock industry accounts for approximately $5 \%$ to $10 \%$ of the overall agricultural contribution (IPCC, 1996).

- The contribution of milk production, including its associated meat production, is approximately $4 \%$ (IPCC, 1996).

- $\quad$ The contribution from milk production alone is estimated at 2.7\% (IPCC, 1996).

There is evidence of increased global average air $\left(+0.74{ }^{\circ} \mathrm{C}\right)$ and ocean temperatures, widespread melting of snow and ice, and rising global average sea level (by $3 \mathrm{~mm}$ annually) (IPCC, 2007a). Human activities result in the emissions of four long-lived greenhouse gases: carbon dioxide $\left(\mathrm{CO}_{2}\right)$, methane $\left(\mathrm{CH}_{4}\right)$, nitrous oxide $\left(\mathrm{N}_{2} \mathrm{O}\right)$ and halocarbons (IPCC, 2007a; b). The global increase in carbon dioxide concentrations is primarily owing to the use of fossil fuels (IPCC, 2007a; b).

It is predicted that climate change will only have a mild impact on livestock production in the United States since most livestock are kept in protected environments (sheds, barns, etc.) and have supplemental feed (Adams et al., 1999). The situation in developing countries is different. In general, the animals are more exposed to the elements, and depend on pasture and other natural forage for nutrition. It is to be expected that animal husbandry will be more sensitive to change in the climate under these conditions.

The effect of climate change on crops is well known, but much less is known about the effects of climate change on livestock (Reilly et al., 1996; McCarthy et al., 2001; Seo \& Mendelsohn, 2006a). Climate can affect livestock directly and indirectly. Direct effects from air temperature, humidity, wind speed and other climate factors influence animal performance: growth, milk production, wool production and reproduction (Houghton, 2001). One of the most evident and important effects of climate change on livestock production is mediated through changes in feed resources. Although indirect, feed resources can have a significant impact on livestock productivity, the carrying capacity of rangelands, the buffering ability of ecosystems and their sustainability, and the distribution of livestock diseases and parasites (Thornton et al., 2007). The main pathways in which climate change can affect the availability of feed resources for livestock are as follows:

- Land use and system changes can lead to different compositions in animal diets and to alteration in the ability of smallholders to manage feed deficits in the dry season (Thornton et al., 2007).

- $\quad$ Changes in the primary productivity of crops, forages and rangelands are probably the most visible effect of climate change on feed resources for ruminants with the end result, for livestock production, a change in the quantity of grains, stovers and rangelands available for dry season feeding (Thornton et al., 2007).

- Changes in species composition in rangelands and some managed grasslands will have significant impact on the types of animal species that can graze them, and may alter the dietary patterns of the communities dependent on them (Thornton et al., 2007).

- $\quad$ The quality of plant material will be altered (from C3 to C4) by increased temperatures and will reduce the digestibility and the rates of degradation of plant species (Minson, 1990), which will lead to reduced nutrient availability for animals (Thornton et al., 2007).

- $\quad$ However, increased levels of $\mathrm{CO}_{2}$ may favour C3 plants (Taub, 2010).

African farmers are known to keep cattle as an insurance policy for when droughts ruin annual crops (Swinton, 1988; Fafchamps et al., 1998). For rural communities, the loss of livestock assets could trigger a collapse into chronic poverty and have a lasting effect on their livelihoods.

\section{The interaction between livestock, temperature and rainfall in Africa}

In a study by Seo \& Mendelsohn (2006b), quantitative methods were used to examine the way in which African farmers adapted livestock management to the range of climates across the continent. A primary choice multinomial logit analysis was used to estimate which livestock species farmers chose during climate change. The model examined the choice of the single species that earns the greatest net revenue on the farm. It was found that the climate influenced livestock ownership. Figures 1 and 2 depict the probabilities that farmers will choose livestock over a range of annual temperatures and precipitation levels. 
The probability of owning livestock increases as annual temperature increases, but decreases as annual rainfall increases.

Pasture may be more productive if located in cooler and wetter climates and the land becomes more profitable for crops under these conditions. Grasslands will turn into forests, and hot, moist conditions will probably influence animal health (Gale et al., 2009; Semenza \& Menne, 2009). Farmers adapt to hot and dry climates by shifting to livestock. However, there is a limit to the way in which dry landscapes can remain suitable for livestock.

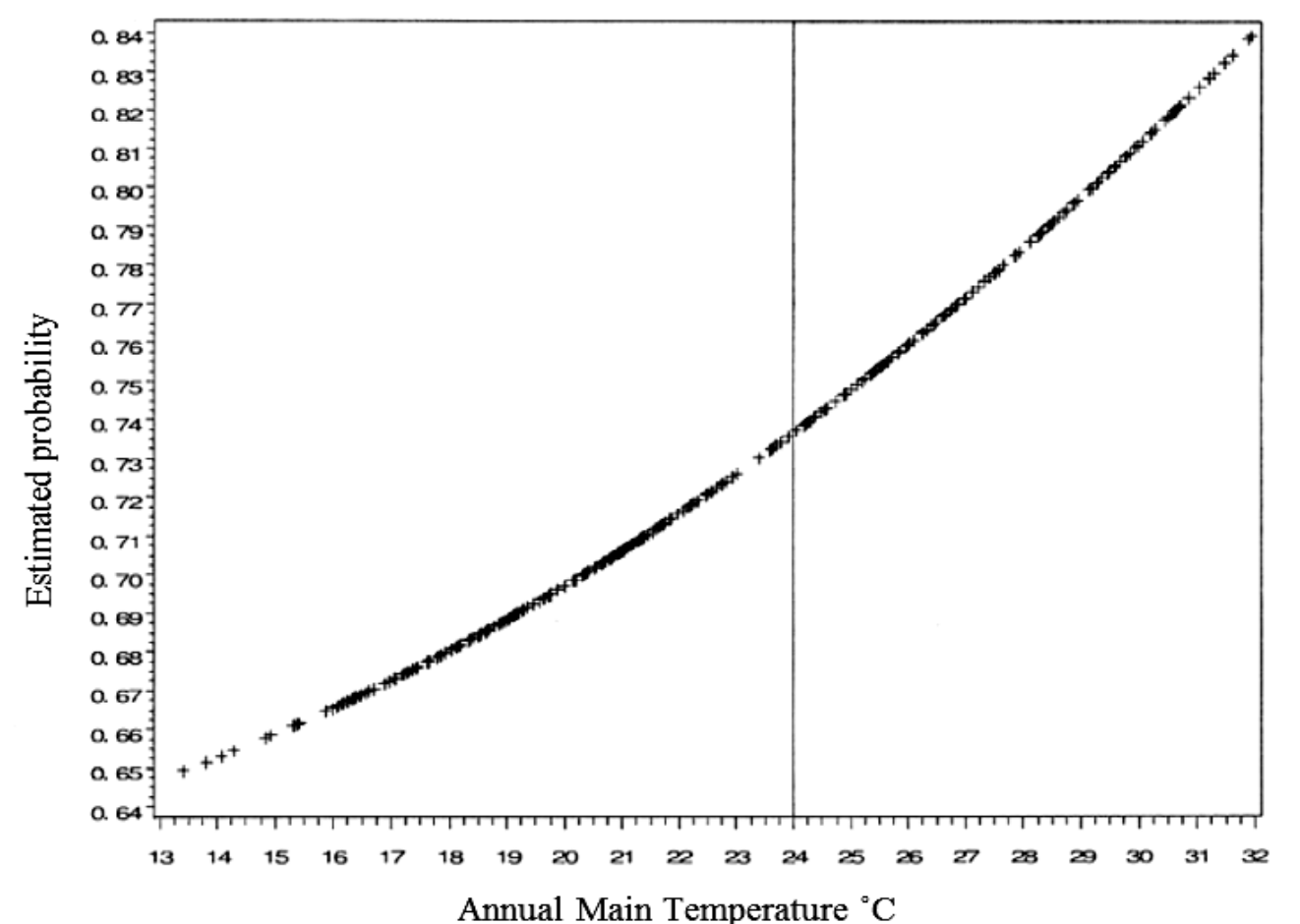

Figure 1 Effect of annual temperature on probability of owning livestock (Seo \& Mendelsohn, 2006b).

Figure 3 depicts the relationship between the probability of choosing a livestock specie and annual temperature. The probability of choosing beef cattle decreases rapidly as temperature rises, as does the probability of choosing dairy cattle (Seo \& Mendelsohn, 2006b).

In contrast, the probability of choosing goats and sheep becomes greater as temperatures rise. With chickens, the estimated probability is bell-shaped (normal distribution), with a maximum at the current mean temperature $\left(22{ }^{\circ} \mathrm{C}\right)$ for Africa. Figure 3 shows that the choice of animals in Africa today is temperature sensitive. Figure 4 depicts the relationship between the probability of choosing an animal species and annual precipitation. Beef cattle, dairy cattle and sheep all decrease as precipitation increases. All three of these species are more productive in grasslands. In contrast, goats and chickens are more likely to be chosen as rain increases. Goats may be able to forage more successfully than large animals in wetter climates. The effect of climate changes may be especially severe on larger farms that specialize in cattle (Seo \& Mendelsohn, 2006b).

In another study, Seo \& Mendelsohn (2006a) examined the climate sensitivity of livestock management in Africa. It was based on a wide-scale survey of African farmers, which measured livestock net revenues. The data were combined with climate and other variables. 


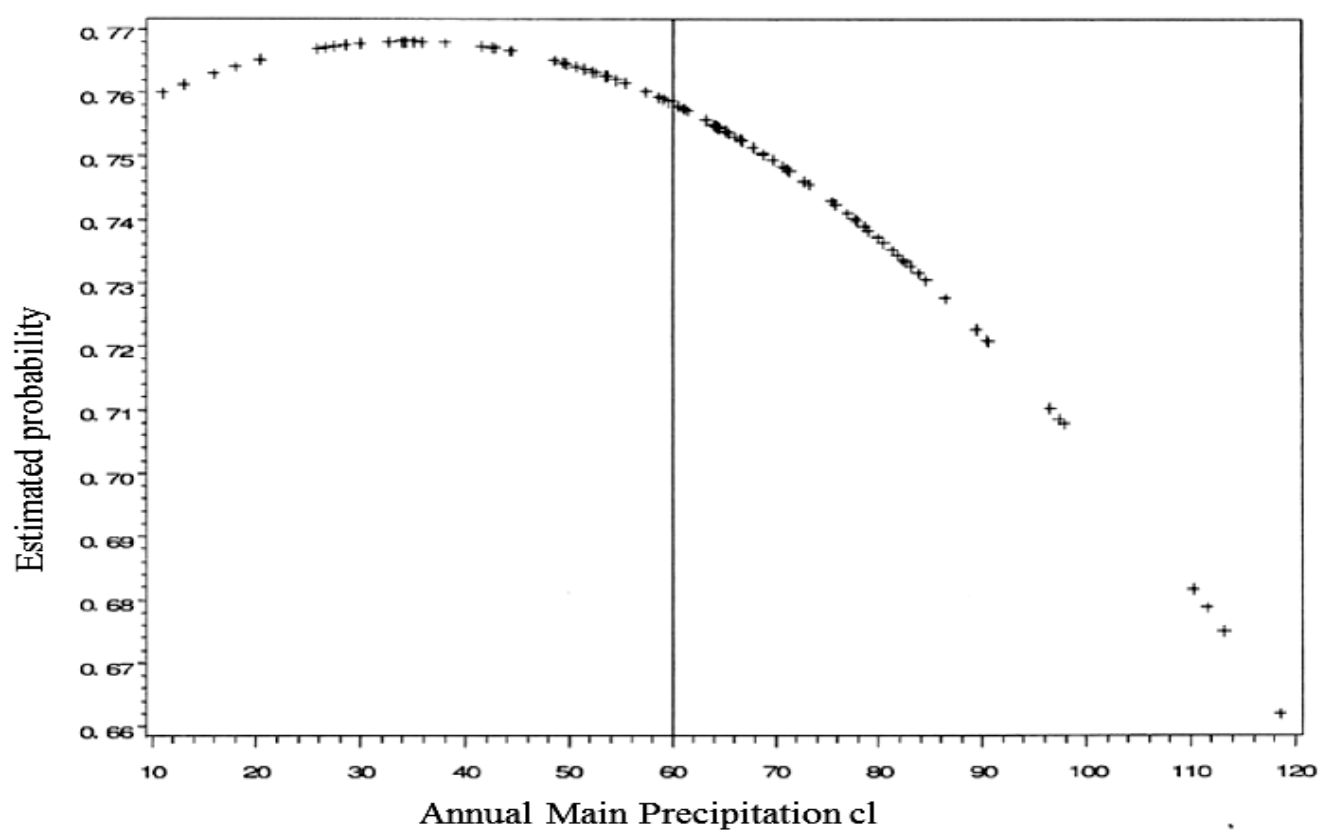

Figure 2 Effect of annual precipitation on probability of owning livestock (Seo \& Mendelsohn, 2006b).

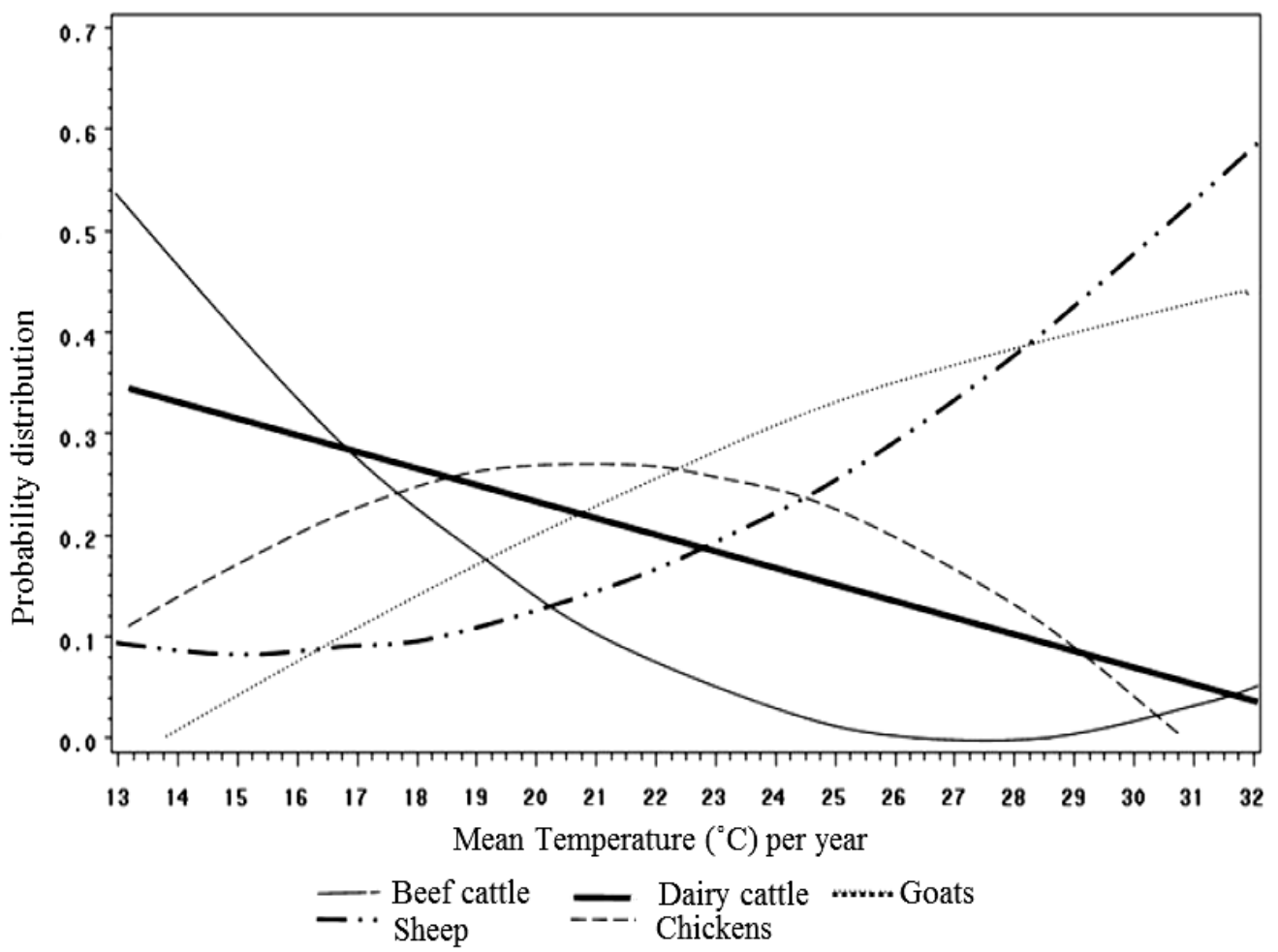

Figure 3 Effect of annual temperature on probability of choice of species (Seo \& Mendelsohn, 2006b). 


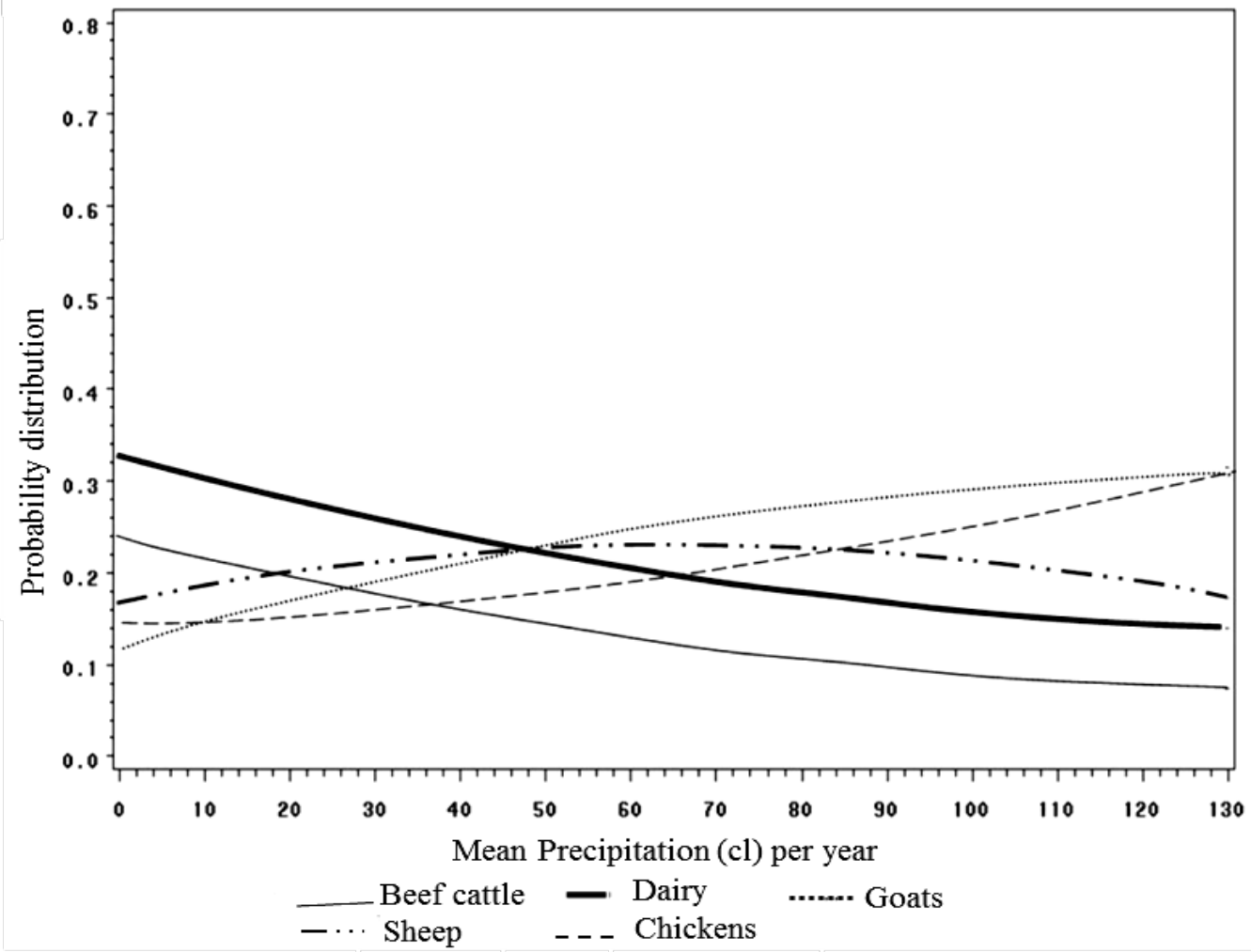

Figure 4 Effect of annual precipitation on probability of choice of species (Seo \& Mendelsohn, 2006b).

The study found that livestock net revenues in Africa are highly sensitive to climate (Seo \& Mendelsohn, 2006a; Kabubo-Mariara, 2009). Climate sensitivity, however, varies according to farm size. Large farms were negatively affected by higher temperature, but small farms not as much. Small farms can switch more easily from temperate animals to heat-tolerant animals and from crops to livestock (Seo \& Mendelsohn, 2006a). The result is that the income from livestock increases for small farms as temperatures rise. Generally in Africa, large farms are more dependent on beef cattle, which are intolerant of high temperatures. For small farmers, livestock provide some protection against the effects of warming, as crops become less desirable (Seo \& Mendelsohn, 2006a).

The effect of higher precipitation on net animal revenue on large farms shows a linear increase, whereas the effect for small farms diminishes with precipitation, so that the net revenue from these two types of farms converges at high levels of precipitation. There are three plausible explanations. First, farmers shift to crops as rainfall increases (Kabubo-Mariara, 2009). Second, grassland changes to forests as rain increases. This reduces the availability of natural grazing for most animals. Third, increases in precipitation heighten the incidence of certain animal diseases (Seo \& Mendelsohn, 2006a).

\section{Direct and indirect effects on livestock}

Climate change will affect animal production in four ways: the impact of changes on livestock feedgrain availability and price; the impact on livestock pastures and forage crop production and quality; changes in livestock diseases and pests; and the direct effects of weather and extreme events on animal health, growth and reproduction (Smith et al., 1996).

The indirect effects of climate-driven changes in animal production may result mainly from alterations in the nutritional environment. Research indicates that changes in climate to a large extent will affect the quality and quantity of forage (Topp \& Doyle, 1996).

The impact of climate change may result in the deterioration of pasture towards lesser quality subtropical C4 grasses in traditional temperate regions as a result of warmer temperatures and less frost. However, there may be increases in production owing to the increase in $\mathrm{CO}_{2}$ levels (Campbell et al., 1995; 
Reilly, 1996). It is also possible that C4 grasses may be replaced with C3 grasses owing to increased levels of $\mathrm{CO}_{2}$ (Taub, 2010).

Climatic restrictions on disease vectors, environmental habits and disease-causing agents are important for keeping animal diseases under control (Stem et al., 1989). Climatic changes may influence livestock health through a number of factors, including the range and abundance of vectors and wildlife reservoirs, the survival of pathogens in the environment, and farming practice (Gale et al., 2009; Semenza \& Menne, 2009). Alterations in temperature and rainfall may result in the spread of disease and parasites into new regions or produce an increase in the incidence to which a particular disease is already prevalent, which will lead to a decrease in animal productivity and increase in animal mortality (Baker \& Viglizzo, 1998).

These factors may interact with each other and also with social and anthropogenic changes, including habitat destruction and changes in land use, which occur globally and locally, and increase mobility of people and movement of goods, including livestock (McDermott et al., 2001; Reiter, 2008). Transmission of infection of zoonotic tick-borne diseases occurs when there is an overlap of activities between reservoir, vector and humans. Changes in climatic conditions may impact on all of these factors involved in disease transmission and their interactions (Gray et al., 2008; Randolph, 2008a). Abiotic factors, such as temperature and day length, impose constraints on when and how ticks quest for hosts (Randolph, 2008b). Beyond vector-borne diseases, intestinal nematodes develop in soil, and factors such as soil humidity and temperature have a strong influence on developmental rates (Brooker et al., 2002). Climate change is bound to have further impact on heat-related mortality and morbidity and on the incidence of climate-sensitive infectious diseases (Patz et al., 2005).

Direct effects are related to radiation, which refers to the exchange of heat between the animal and the environment. This can be affected by temperature, humidity and wind speed. With current climatic conditions, the animal's current inability to dissipate environmental heat already causes heat stress in many species for at least part of the year (Fuquay, 1981). Heat stress has various detrimental effects on livestock (Fuquay, 1981). There is a range of thermal conditions within which animals can maintain a relatively stable body temperature through behavioural and physiological means (Bucklin et al., 1992). Heat stress is a result from the animal's inability to dissipate sufficient heat to maintain homeothermy. High ambient temperature, relative humidity and radiant energy compromise this ability of animals to dissipate heat. This result in an elevated body temperature, which in turn initiates compensatory and adaptive mechanisms to re-establish homeothermy and homeostasis. The so-called re-adjustment may be of economic interest to human beings, but is essential to survival for the animals (Stott, 1981).

An increase in air temperature, as associated with climate change, will have a direct effect on animal performance through alterations in the heat balance. There are four modes of heat transfer: radiation, convection, evaporation and conduction. Evaporation is one of the most important methods of heat transfer in animals as it does not depend on a temperature gradient (Ingram \& Mount, 1975). Humidity becomes more important since it directly affects the evaporation rate. Therefore, the temperature humidity index (THI) becomes relevant under conditions of high temperature and high humidity (Thom, 1958).

\section{The effect of climate change on dairy and beef production}

When evaluating the effect of climate change on dairy and beef production, it is important to look at the total picture and assess future measures to curb greenhouse gas emission from dairying and to optimize dairy and beef production for a secure food supply for the future.

These effects on dairy and beef production can be predicted (own speculation):

- $\quad$ Decrease in fodder production from dry land and irrigated pastures, with a resulting rise in feed costs

- $\quad$ Decrease in grain production, resulting in higher feed costs

- $\quad$ Decreased milk production

- $\quad$ Reduced animal weight gain

- $\quad$ Decrease in reproduction rate

- $\quad$ Lower feed conversion efficiencies

- Increase in the prevalence of vector-borne diseases

- Increase in the prevalence of internal parasite infestation

These effects will be more severe in pastoral systems and in areas where an increase in temperature and decrease in precipitation are predicted. The opposite may be true for areas which will experience longer 
cold spells and an increase in precipitation. However, the demarcation of these areas is subject to unquantifiable speculation and change.

Dairy cattle show heat stress when the temperature humidity index (THI) is higher than 72 (Armstrong, 1994). Their threshold for heat tolerance depends on the genotype as well as production level. Animals on higher production levels tend to be more sensitive to high temperature and humidity (Johnson, 1987; Hahn, 1989).

The intensity of heat stress and the length of the period recovery play important roles in the ability to recover from a stress period (THI above 72) (Valtorta et al., 1996). In areas of the world where heat stress is already considered a problem, the daily average of stress hours is calculated at 13 . Paleoclimatologists predict that average daily stress hours in the same areas may increase to 17 by 2025 (Valtorta et al., 1996).

Dairy cows subjected to heat-wave conditions associated with climate change have shown a $10 \%$ $14 \%$ reduction in milk production. These animals did not recover, even after conditions returned to normal (Valtorta, 2002).

Other general impacts of climate change on dairy production could include reduced animal weight gain, lower reproduction rates and lower feed conversion rates in hotter areas. More mixed impacts are predicted for cooler areas (Aydinalp \& Cresser, 2008). The reproduction rate in dairy cows (especially high producing breeds) is currently a concern, as the inter-calving period (ICP) tends to increase over time as production increases (Olori et al., 2002). This trend will probably become an even bigger problem as heat and nutritional stress increase.

All methods to assist animals in coping with heat stress will alleviate the impact of global change on animal response and performance. The three basic management inputs that will alleviate heat stress in dairy cows are the physical modification of the environment; the genetic development of less sensitive breeds; and improved nutritional management (Beede \& Collier, 1986).

The estimated global demand for meat is expected to double between 1999 and 2050 (Steinfeld et al., 2006). The global numbers of meat-producing animals will have to increase to meet this demand, which will lead to an increase in greenhouse gas emissions from the total production cycle. This substantial increase in demand is due mainly to increased human population numbers and augmented incomes (Delgado et al., 1999). Subsistence, communal and emerging livestock farmers have huge roles to play in meeting this demand since their production systems output can improve substantially with appropriate interventions. The question remains, how will climate change affect beef production and its expansion?

Beef cattle make up a high percentage of the so-called meat producing animals in Africa and South America in particular. Africa is in the unique position of having a high number of beef cattle breeds that have adapted to prevailing conditions (Scholtz, 1988; 2005; Scholtz \& Theunissen, 2010).

Beef is produced mainly on natural pastures, with finishing taking place in custom feedlots. Both systems are extremely vulnerable as natural pastures and feed crops will be affected by climate change. With expected temperature rises of $2{ }^{\circ} \mathrm{C}$ to $5{ }^{\circ} \mathrm{C}$, a grazing capacity loss of between $30 \%$ and $50 \%$ can be expected (Furstenberg \& Scholtz, 2008; Romanini et al., 2008).

With an increase in demand and the possible detrimental effect of climate change on production output, it is important to attempt to mitigate the negative effect that climate change may have on beef cattle production. The mitigation factors for beef and dairy will be more or less the same. The only differences are that beef cattle are more tolerant to heat stress and the milk-producing ability is not so paramount.

Potential mitigation and adaptation factors that could be incorporated into dairy and beef production systems (own speculation) include:

- $\quad$ Ensuring more efficient nutrition

- Utilizing continuous genetic improvement to breed more efficient animals (smaller, lighter in colour, reproductively sound, high feed to milk conversion and milk output, high feed to meat conversion and substantial disease tolerance)

- Modifying production systems in order to leave a smaller carbon footprint with less emissions, fewer waste products and lower energy requirements

- Modifying production systems to become less dependent on water for production and irrigation

- $\quad$ Adopting a seasonal dairy production system

- Improving the emerging beef cattle sector (higher output in the form of reproduction, survival, growth, lower stocking rates and better resource utilization) 
- $\quad$ Developing more drought-resistant dry land crops and pastures for dairy consumption

- $\quad$ Adopting more effective and environmentally friendly farming practices

\section{The effect of climate change on small ruminants}

As temperatures increase as a result of climate change, the probability of choosing sheep and goats as livestock species will increase (Seo \& Mendelsohn, 2006b). It can be expected that natural resource-based livelihoods will be affected first and to the greatest extend. The promotion of sustainable agriculture and livestock rearing will be vital to ensure that the impact of climate change is minimized. Indigenous populations will probably be confronted with the direct consequences of climate change firstly, because they depend on the environment and natural resources to subsist. (UNPFII) Climate changes exacerbate the difficulties faced by indigenous communities. Addressing climate change will involve rearing animals that are robust, more heat tolerant, more disease resistant, and are relatively adaptable to the difficult conditions. Small ruminants contribute enormously towards the promotion of livelihood security and as an insurance to cope with crop failure, particularly for rural, small and marginal farmers (Pasha, 2000; Misra, 2005). Livestock owners maintain their stock by grazing on community lands and using family labour with negligible economic inputs and marginal outputs (Chauhan \& Moorthi, 1999). Indigenous farmers create ways to combat the impacts of climate change, through traditional knowledge and other technologies. (UNPFII). It is common among families to rear one to three sheep or goats. Also, goat farming is increasingly being taken up by the peri-urban poor population owing to easy market access and as a source of nutritional security for the household (Pollot \& Wilson, 2009; SA PPLPP).

Although small ruminants are often cited for negatively impacting on the environment, they can improve soil and vegetation cover. By consuming biomass, which otherwise might provide the fuel for bush fires, by controlling shrub growth and by dispersing seeds through their hooves and manure, small ruminants can contribute to plant biodiversity. Trampling can stimulate grass tilling, advance seed germination, and break up hard soil crusts (Steinfeld et al., 2006).

One advantage of sheep and goats is that they produce meat and in some instances fibre. In future fibre-based products will have to report on their environmental credentials. This drive is an opportunity for wool growers since wool's major competitors in the global fibre market are cotton and synthetic fibres, both of which are highly energy intensive and significant emitters of greenhouse gases (Gluckman, 2010).

Climate change is likely to have implications for the wool industry, principally through its effects on forage and water resources, land carrying capacity and sustainability, animal health, and competition with other sectors, in particular cropping. The extent of these impacts will depend on how climate change is expressed in each wool-producing region and the specific way in which it will probably have and effect on both wool quantity and quality. A reduced productivity in marginal areas can be predicted, and a possibly higher productivity in higher rainfall regions. Changes in climate can possible also increase plant and dust contamination as well as changes in mean fibre diameter and staple strength. A more temperate climate might reduce the demand for apparel wool fibre and could in turn affect the national and international wool markets. Even though the wool industry will be significantly affected by the effects of climate change, it is expected that it should be relatively robust to it (Gluckman, 2010). If farmers can effect early adaptations they can reduce the effect from climate change. Examples of adaptations are efforts to produce low-emission grazing systems, more sustainable rangeland management (Harle et al., 2007). Australia's Sheep Cooperative Research Centre estimates that $66 \%$ of agricultural emissions are released as methane. They have been trying to identify a genetic link that causes some sheep to produce less methane than others (Meadows, 2009).

In contrast to sheep and cattle that avoid bush thickets, browsing goats prune and inhibit bush growth that in turn will advance the growth of grasses. With the right management and grazing controls, a goat industry could be a useful tool for sound rangeland management. Grazing by goats can provide biological weed control. Biological control is a more environmentally acceptable form than certain other methods of control. Grazing treatments can be applied to difficult terrain where access is limited. However, attention must be paid to adequate fencing. Grazing can provide continuous, therefore more effective pressure on numerous weeds that have staggered or delayed germination cycles. Clovers are least favoured. Therefore, while weeds are being grazed out, the more valuable clovers build up. Goats can be run with sheep and cattle. Their grazing is complementary to both. So goats can be added to sheep or cattle camps with little loss in production of the sheep or cattle. Researchers in Brazil are investigating supplementing dairy cow milk 
with goat milk in order to compensate for the effects that climate change will have on the dairy industry (Borrell, 2009).

\section{The effect of climate change on monogastric animals}

Poultry meat and egg production are the most efficient animal protein production systems. Poultry meat production is the most environmentally efficient (smallest carbon footprint per unit product produced), followed by pork and mutton (primarily lamb) with beef the least efficient (Williams et al., 2006). This results from several factors, including the low overheads of poultry breeding stock (much greater fecundity of hens; 250 progeny per hen each year versus one calf per cow); efficient feed conversion; high daily weight gain of poultry (made possible by genetic selection and improved dietary formulation) (Williams et al., 2006).

Poultry and pigs consume high-value feeds and rely on arable land, as their nutritional needs are overwhelmingly met by arable crops. These production systems often depend to a large extent on concentrated feed. Thus the major environmental impacts on them are associated with production outside the farm and on-farm delivery of concentrated feed (Van der Werf et al., 2005). In terms of the impact of climate change on primary energy consumed, ruminants are about $50 \%$ higher than pig or poultry meat production (Williams et al., 2006). However, although ruminant meat incurs more burdens than pig or poultry meat, ruminants can derive nutrition from land that is unsuitable for arable crops (Williams et al., 2006).

The adoption of organic poultry production systems is not a solution. Most organic animal production reduces primary energy use by $15 \%$ to $40 \%$, but organic poultry meat and egg production increase energy use (Van der Sluis, 2007). Free-range (non-organic) poultry increases energy use for meat by $20 \%$ and for eggs by $15 \%$, compared with all-housed production (Van der Sluis, 2007). The benefits of the lower energy needs of organic feeds are over-ridden by lower bird performance. Organic poultry has a higher food conversion ratio and a longer growing period, resulting in a net increase in energy requirement for organic poultry meat production. Organic egg production needs more energy than non-organic and increases most environmental burdens (except pesticides), but the required land area more than doubles (Van der Sluis, 2007).

Pork production shows a reduction of all environmental burdens from organic production, but uses considerably more land to produce feed. Finishing pigs at a heavier weight shows a slight reduction in burdens, mainly as a result of reducing the overheads of breeding piglets (Williams et al., 2006). The choice of indoor or outdoor sow housing has a negligible effect on pork production contribution to climate change (Williams et al., 2006).

The bulk of greenhouse gas and ammonia (indirect source of greenhouse gas emissions) from pig production systems are from pig housing and slurry storage (Van der Peet-Schwering et al., 1999). These emissions can be reduced by:

- $\quad$ Lowering the concentrations of urea and ammonia in the slurry

- $\quad$ Lowering the temperature of the slurry

- $\quad$ Reducing the emitting surface area

- $\quad$ Reducing the $\mathrm{pH}$ of the slurry

Various housing techniques have been developed to reduce emissions. A combination of housing and feeding measures seems most promising to achieve a substantial reduction in emissions at relatively low cost (Van der Peet-Schwering et al., 1999).

\section{Conclusion}

The impacts of climate change on agricultural production and livestock are difficult to establish and distinguish from other changes in the natural and human environments. Many non-climatic drivers are interconnected with climate change impact such as migration, overgrazing of natural pastures, alteration in livestock management, and change in human and livestock population.

Some areas will benefit from the increase in agricultural production as a result of climate change and others will suffer decreases. These regional increases and decreases are not expected to result in large deviations in food production over the next century on a global scale. Vulnerability to climate change depends on physical, biological and socio-economic characteristics. Low-income populations that depend on subsistence agriculture are particularly at risk of being affected. The impact on regional and local food 
production will be more severe in low latitude regions, arid and semi-arid areas, especially the rain-fed, nonirrigated production systems. Many of these risk areas are situated in South and Southeast Asia and Africa. The reduction in animal production can be substantial and may result in significant costs for these regions.

The dilemma with climate change is the uncertainty surrounding it and its timeframes. It is uncertain which areas, regions and countries will be affected by the changes and to what extent. This may lead to a reluctant approach to the initiation of mitigating measures. Livestock production in Africa and Southern Africa, especially its developing component, is vulnerable and at high risk of being severely affected by climate change. Constant research, education and sensitization are needed in order to adapt to and combat the possible effects of climate change at local, national and regional level.

\section{Acknowledgement}

The authors are grateful to fellow scientists of the Animal Research Division, Döhne Agricultural Development Institute, for sourcing useful information that was used in writing this article.

\section{References}

Adams, R.M, McCarl, B.A., Segerson, K., Rosenzweig, C., Bryant, K. J., Dixon, B.L., Conner, A., Evenson, R.E. \& Ojima D., 1999. The economic effect of climate change on US agriculture. In: The Economic Impact of Climate Change on the Economy of the United States. Eds: Mendelsohn, R. \& Neumann, J., Cambridge: Cambridge University Press.

Armstrong, D.V., 1994. Heat stress interaction with shade and cooling. J. Dairy Sci. 77, 2044-2050.

Aydinalp, C. \& Cresser, M.S., 2008. The effect of global climate change on agriculture. American-Eurasian J. Agric. Environ. Sci. 3, 672-676.

Baker, B. \& Viglizzo, J.E., 1998. Rangelands and livestock. Chapter 9. In: Handbook of methods for climate change impact assessment and adaptation strategies. Eds: Feenstra, J.F., Burton, I., Smith, J.B. \& Tol, R.S., IVM/UNEP Version 2.0 Accessed September $22^{\text {nd }} 2002$.

Beede, D.K. \& Collier, R.J., 1986. Potential nutritional strategies for intensively managed cattle during thermal stress. J. Anim. Sci. 62, 543-554.

Borrell, B., 2009. Got goat's milk? The quest to save dairy from climate change. ScientificAmerican.com.

Brooker, S., Hay, S.I. \& Bundy, D.A.P., 2002. Tools from ecology: useful for evaluating infection risk models? Trends Parasitol. 18 (2), 70-74.

Bucklin, R.A., Hahn, G.L., Beede, D.K. \& Bray, D.R., 1992. Physical facilities for warm climates. In: Large Dairy Herd Management. Eds: Van Horn, H.H. \& Wilcox, C.J., Am. Dairy Sci. Assoc., Champaign IL 61820, 609-618.

Campbell, B.D., McGeon, G.M., Gifford, R.M., Clark, H., Stafford Smith, D.M., Newton, P.C.D. \& Lutze, J.L., 1995. Impacts of atmospheric composition and climate change on temperate and tropical pastoral agriculture. In: Greenhouse 94. Eds: Pearman, G. \& Manning, M., CSIRO, Canberra, Australia.

Chauhan, S.K. \& Moorthi, T.V., 1999. Income and employment pattern. In: Economics of sheep farming. Mittal Publication, New Delhi, India.

Delgado, C.M., Rosegrant, H., Steinfeld, S., Ehui \& Courbois, C., 1999. Livestock to 2020: The next food revolution. IFPRI, FAO, and ILRI, Washington, D.C., USA.

Easterling, W.E. \& Aggarwal, P.K., 2007. Food, Fibre and Forest Products. In: Climate change 2007: Impacts, adaptation and vulnerability. Contribution of Working Group II to the Fourth Assessment Report of the Intergovernmental Panel on Climate Change. Eds: Parry, M.L., Canziani, O.F., Palutikof, J.P., Van der Linden, P.J. \& Hanson, C.E., Cambridge, Cambridge University Press. pp. 273-313.

Fafchamps, M., Udry, C. \& Czukas, K., 1998. Drought and saving in West Africa: Are livestock a buffer stock? J. Dev. Econ. 55, 273-305.

FAO, 2007. Adaptation to climate change in agriculture, forestry, and fisheries: perspective, framework and priorities. FAO, Rome.

Fuquay, J.W., 1981. Heat stress as it affects animal production. J. Anim. Sci. 52, 164-174.

Furstenburg, D. \& Scholtz, M.M., 2008. Global climate change and animal production in Southern Africa: A short review. Poster presented at $10^{\text {th }}$ World Congress on Animal Production, Cape Town, South Africa. 
Gale, P., Brouwer, A., Ramnial, V., Kelly, L., Kosmider, R., Fooks, A.R. \& Snary, E.L., 2009. Assessing the impact of climate change on vector-borne viruses in the EU through the elicitation of expert opinion. Epidemiol. Infect. 1-12.

Gill, M. \& Smith, P., 2008. Mitigating climate change: the role of livestock in agriculture. Livestock and Global Change Conference Proceeding. May 2008, Tunisia.

Gluckman, E., 2010. Climate change - Pro-active solutions in the wool industry. Wolboer/Wool Farmer, May 2010, 23.

Gray, J.S., Dautel, H., Estrada-Peña, A., Kahl, O. \& Lindgren, E., 2008. Effects of climate change on ticks and tick-borne diseases in Europe. Interdisciplinary Perspectives on Infectious Diseases, vol. 2009, Article ID 593232, 12 pages, 2009. doi:10.1155/2009/593232.

Hahn, G.L., 1989. Bioclimatology and livestock housing: theoretical and applied aspects. Proc. Brazilian Workshop on Animal Bioclimatology. Jaboticabal, Brazil. p. 15.

Harle, K.J., Howden, S.M., Hunt, L.P. \& Dunlop, M., 2007. The potential impacts of climate change on the Australian wool industry by 2030. Agr. Syst. 93, 61-89.

Houghton, J.T., 2001. Climate Change 2001: The Scientific Basis. Contribution of Working Group I to the third assessment report of the Intergovernmental Panel on Climate Change. Cambridge: Cambridge University Press, UK.

Hussein, K., Calvosa C., Roy, R. and the Global Environmental Facility Unit/IFAD, 2008. The effects of climate change on small holder farmers in West and Central Africa. Published for the 10th Meeting of the Africa Partnership Forum, April 2008, Tokyo, Japan.

IFAD, 2010. Livestock and climate change. Livestock Thematic Papers. Tools for project design. www.ifad.org

Ingram, D.L. \& Mount, L.E., 1975. Man and Animals in Hot Environments. Springer-verlag, New York. Heidelberg, Berlin.

IPCC, 1996. Climate change 1995. Impacts, adaptations and mitigation of climate change: ScientificTechnical Analyses. Contribution of Working Group II to the Second Assessment Report of the Intergovernmental Panel on Climate Change.

IPCC, 2007a. Summary for Policymakers. In: Climate change 2007: Impacts, adaptation and vulnerability. Contribution of Working Group II to the Fourth Assessment Report of the Intergovernmental Panel on Climate Change: Parry, M.L., Canziani, O.F., Palutikof, J.P., Van der Linden, P.J. \& Hanson, C.E., Cambridge, Cambridge University Press: 1000.

IPCC, 2007b Fourth Assessment Report, Working Group III.

Johnson, H.D., 1965. Response of animals to heat. Meteor. Mon. 6, 109-122.

Johnson, H.D., 1987. Bioclimate effects on growth, reproduction and milk production. Part H, Chapter 3. In: Bioclimatology and the Adaptation of Livestock. Elsevier, Amsterdam, The Netherlands.

Jones, R.N., 2000. Manage uncertainty in climate change projections. Issues for impact assessment. Climatic change 54, 403-419.

Kabubo-Mariara, J., 2009. Global warming and livestock husbandry in Kenya: Impacts and adaptations. Ecol. Econ. 68, 1915-1924.

Koneswaran, G. \& Nierenberg, D, 2008. Global farm animal production and global warming: Impacting and mitigating climate change. Environ. Health Persp. 116, 578-582.

McCarthy, J., Canziani, O.F., Leary, N.A., Dokken, D.J. \& White, C., 2001. Climate Change 2001: Impacts, Adaptation, and Vulnerability. Contribution of Working Group II to the third assessment report of the Intergovernmental Panel on Climate Change. Cambridge: Cambridge University Press.

McDermott, J.J., Kristjanson, P.M., Kruska, R.L., Reid, R.S., Robinson, T.P., Coleman, P.G., Jones, P.G. \& Thornton, P.K., 2001. Effects of climate, human population and socio-economic changes on tsetsetransmitted trypanosomiasis to 2050. In: World Class Parasites - Vol. 1. The African Trypanosomes, Eds: Seed, R. \& Black, S., Kluwer, Boston, 25-38. ISBN 0-7923-7512-2.

Meadows, S., 2009. Good news for climate change: Australian scientists to breed sheep that burp less. http://optimistworld.com/

Minson, D.J., 1990. Forage in Ruminant Nutrition. Academic Press, San Diego.

Misra, A.K., 2005, Contingency planning for feeding and management of livestock during drought. In: Drought Management. Eds: Sharma, K.D. \& Ramasastri, K.S., Allied Publishers Pvt. Ltd., New Delhi, India. 
Olori, E., Meuwissen, T.H.E. \& Veerkamp, R.F., 2002. Calving interval and survival breeding values as measure of cow fertility in a pasture-based production system with seasonal calving. J. Dairy Sci. 85, 689-696.

Pasha, S.M., 2000. Economy and Ecological Dimensions of Livestock Economy. Commonwealth Publishers, New Delhi, India.

Patz, J.A., Campbell-Lendrum, D., Holloway, T. \& Foley, J.A., 2005. Impact of regional climate change on human health. Nature 438 (17 November 2005), 310-317.

Pitesky, M.E., Stackhouse, K.R. \& Mitloehner, F.M., 2009. Clearing the Air: Livestock's Contribution to Climate Change. Adv. Agron. 103, 1-40.

Pollot, G. \& Wilson, R.T., 2009, Sheep and Goats for diverse products and profits (FAO Rome).

Randolph, S.E., 2008a. Dynamics of tick-borne disease systems: minor role of recent climate change. Rev. Sci. Tech. Off. Int. Epiz. 27 (2), 367-381.

Randolph, S.E., 2008b. The impact of tick ecology on pathogen transmission dynamics. Ticks: Biology, Disease and Control. Eds: Bowman, A.S. \& Nuttall, P.A., Cambridge University Press, 978-0-52186761-0. pp. 40-72.

Reilly, J., Baethgen, W., Chege, F., Van de Geijn, S., Erda, L., Iglesias, A., Kenny, G., Patterson, D., Rogasik, J., Rotter, R., Rosenzweig, C., Somboek, W., Westbrook, J., Watson, R., Zinyowera, M., Moss, R. \& Dokken, D., 1996. Agriculture in a changing climate: Impacts and adaptations. Climate Change 1995: Intergovernmental Panel on Climate Change Impacts, Adaptations, and Mitigation of Climate Change. Cambridge University Press, Cambridge. pp. 427-468.

Reiter, P., 2008. Climate change and mosquito-borne disease: knowing the horse before hitching the chart. Revue Scientifique et Technique Office International des Epizooties 27, 383-398.

Romanini, C.E.B., Nääs, I.D.A., D’Alessandro Salgado, D., Lima, K.A.O., do Valle, M.M, Labigalini, M.R., de Souza, S.R.L., Menezes, A.G. \& de Moura, D.J., 2008. Impact of global warming on Brazilian beef production, Livestock environment VIII, 31 August - 4 September 2008, Iguassu Falls, Brazil $701 P 0408$.

SA PPLPP. Small Ruminants : Common Property Resources. NDDB house (6th floor), PB 4906, Safdarjang Enclave, New Delhi. http://sapplpp.org/thematicfocus/small-ruminants.

Scholtz, M.M., 1988. Selection possibilities for hardy beef breeds in Africa: The Nguni example. Proc. $3^{\text {rd }}$ World Cong. Sheep and Beef Cattle Breeds. 2, 303-319.

Scholtz, M.M., 2005. The role of research and the seed stock industry in the in situ conservation of livestock genetic resources. Proc. $4^{\text {th }}$ All Africa Conf. Anim. Agric. Arusha, Tanzania, 311-316.

Scholtz, M.M. \& Theunissen, A., 2010. The use of indigenous cattle in terminal cross-breeding to improve beef cattle production in Sub-Saharan Africa. Anim. Gen. Res. Inf. 46, 33-39.

Semenza, J.C. \& Menne, B., 2009. Climate change and infectious diseases in Europe. Lancet ID, 9, 365-375.

Seo, S.N. \& Mendelsohn, R., 2006a. Climate change impacts on animal husbandry in Africa: A Ricardian analysis. CEEPA Discussion Paper No. 9, Centre for Environmental Economics and Policy in Africa, University of Pretoria, South Africa.

Seo, S.N. \& Mendelsohn, R., 2006b. Climate change adaptation in Africa: A microeconomic analysis of livestock choice. CEEPA Discussion Paper No. 19, Centre for Environmental Economics and Policy in Africa, University of Pretoria, South Africa.

Smith, B., McNabb, D. \& Smithers, J., 1996. Agricultural adaptation to climatic variation. Climate change 43, 7-29.

Steinfeld, H., Gerber, P., Wassenaar, T., Castel, V., Rosales, M. \& De Haan, C., 2006. Livestock’s long shadow: Environmental issues and options. Rome, FAO.

Stem, E., Mertz, G.A., Stryker, J.D. \& Huppi, M., 1989. Changing animal disease patterns induced by the greenhouse effect. In: The Potential Effects of Global Change on the United States: Appendix C Agriculture, Volume 2. Eds: Smith, J. \& Tirpack, D.A., US Environmental protection agency, Washington, D.C. pp. 11-38.

Stot, G.H., 1981. What is animal stress and how is it measured? J. Anim. Sci. 52, 150-153.

Swinton, S., 1988. Drought survival tactics of subsistence farmers in Niger. Human Ecology 16, 123-144.

Thom, E.C., 1958. Cooling-degree days. Air-conditioning, heating and ventilation, July 65-72.

Taub, D., 2010. Effects of rising atmospheric concentrations of carbon dioxide on plants. Nature Education Knowledge 3, 21. 
Thornton, P. \& Herrero, M., 2008. Climate Change, Vulnerability, and Livestock Keepers: Challenges for Poverty Alleviation. In: Livestock and Global Climate Change Conference Proceeding, May 2008, Tunisia.

Thornton, P., Herrero, M., Freeman, A., Mwai, O., Rege, E., Jones, P. \& McDermott, J., 2007. Vulnerability, climate change and livestock - Research opportunities and challenges for poverty alleviation. SAT eJournal 4 (1), 1-23.

Topp, C.F.E. \& Doyle, C.J., 1996. Simulating the impacts of global warming on milk and forage production in Scotland. 1. The effects on dry matter yield of grass and grass-white clover stands. Agr. Syst. 52, 213-242.

UNPFII. Climate change and indigenous peoples. http://www.un.org/esa/socdev/unpfii//

Valtorta, S.E., Gallardo, M.R., Castro, H.C. \& Castelli. M.C., 1996. Artificial shade and supplementation effects on grazing dairy cows in Argentina. Trans ASEA 39, 233-236.

Valtorta, S.E., Leva, P.E., Gallardo, M.R. \& Scarpati, O.E., 2002. Milk production responses during heat wave event in Argentina. 15th Conference on Biometereology and Aerobiology - 16th Int. Congress on Biometeorology, Kansas City, MO. American Meteorological Society, Boston, 98-101.

Van der Peet-Schwering, C.M.C., Aarnink, A.J.A., Rom, H.B. \& Dourmad, J.Y., 1999. Ammonia emissions from pig houses in the Netherlands, Denmark and France. Livest. Prod. Sci. 58, 265-269.

Van der Sluis, W., 2007. Intensive poultry production better for global warming. Wrld Poult. 23 (2), 28-30.

Van der Werf, H.M.G., Petit J. \& Sanders, J., 2005. The environmental impacts of the production of concentrated feed: the case of pig feed in Bretagne. Agr. Syst. 83, 153-177.

Williams, A.G., Audsley, E. \& Sandars, D.L., 2006. Determining the environmental burdens and resource use in the production of agricultural and horticultural commodities. Main Report. Defra Research Project IS0205. Bedford: Cranfield University and Defra. Available on www.silsoe.cranfield.ac.uk, and www.defra.gov.uk. 